\title{
El cine y los imaginarios culturales de la ciudad violentada en Roberto Bolaño.
}

\section{The Cinema and the Cultural Imaginaries of the Violated City in Roberto Bolaño.}

\begin{abstract}
Resumen
El presente artículo examina tres obras de Roberto Bolaño que sitúa mediante la narratología y la antropología cultural a las efigies bolañianas, quienes exponen nuevos usos para el espacio urbano esquivando un imaginario simbólico controlado por las funciones espaciales de una sobremodernidad encubierta. De esa manera, el análisis abarca su negatividad axiológica, su anomalía ética y la inconstancia de sus definiciones constitutivas como personajes, que son representaciones del mal en el pensamiento moderno en América. Se trata de una trayectoria del vacío existencial, impresiones que se irán repitiendo intermitentemente como estructuras antropológicas a partir del régimen de la imagen.
\end{abstract}

Palabras claves Antropología, cine, imagen, no lugar, vacío.

\begin{abstract}
The present article examines three works by Roberto Bolaño, who put the ballistic Effigies through narratology and cultural anthropology, who expose new uses for urban space by avoiding a symbolic imaginary controlled by the spatial functions of a disguised overmodernity. In this way, the analysis covers its axiological negativity, its ethical anomaly and the inconstancy of its constitutive definitions as characters, which are representations of evil in
\end{abstract}


modern thought in America. It is a trajectory of the existential vacuum, impressions that will be repeated intermittently as anthropological structures from the regime of the image.

Keywords

Anthropology, cinema, image, not place, empty.

\section{El cine como texto palimpséstico}

América Latina ha podido soportar a los embistes de los siglos, desde su descubrimiento, hasta la industrialización, pero no ha podido soportar de la misma forma las heridas psicogeográficas, causadas por el saqueo, la corrupción, la violencia y el caos. Todas estas fracturas han configurado el imaginario simbólico, que establece la realidad de los pensamientos y las prácticas de la sociedad, que nada tienen que ver con lo jurídico, sino con lo informal; es decir, cuando una sociedad considera que algo es normal, el mensaje se convierte en un reflejo que se reproduce de forma intermitente los colectivos sociales. Bajo este mismo eje, en la narrativa del escritor chileno Roberto Bolaño (1953-2003), auto declarado cinéfilo empedernido, nos ofrece diversos puntos de vista; lo cual implica, recoger esas voces ficticias que exponen, y se vinculan con la realidad, tanto literaria como extratextual, a través de un diálogo abierto y conectado con el devenir cultural de Latinoamérica y su relación con el mundo.

En el presente artículo, el propósito es que a través de la diégesis, con el objeto de abordar la construcción imaginaria y simbólica de la cuestión de "lo latinoamericano", tal y como señala Neige Sinno en Lectores entre líneas: "En la geografía imaginaria de Bolaño, los países latinoamericanos son escenarios oníricos, donde cohabitan constantemente ficción y realidad" (61). En este sentido, en el umbral del siglo XXI, Bolaño utiliza el cine como una herramienta que le ayudará a exponer la cultura de la imagen para las representaciones 
urbanas. Además, su narrativa hipertextual ${ }^{1}$ discurre a través de los variados territorios fraccionados, mediante los cuales presenta una urbe contrapuesta al quebranto de sus valores más auténticos. En el otro extremo se puede apreciar la hipertrofia del mundo, teniendo como eje temático de referencia tanto el cine, como la literatura, a partir del presente análisis con base en tres de sus obras: Los detectives salvajes (1998), Putas asesinas (2001) y 2666 (2004). Nada mejor que estas tres obras que sirvan de estrategia creativa del hilo conductor para cimentar el análisis de nuestro discurso literario, aunque pareciera que sería mejor sólo enfocarnos a una lectura, pero al hacerlo no podríamos trabajar con los hipertextos cinéfilos que a continuación iremos analizando.

Se trata de una lectura hipertextual, ya que el hipertexto nos proporciona una herramienta extraordinaria (atajo), donde el autor chileno muestra esa cultura básica y sus convenciones lingüísticas, especialmente, con fundamento a la información de las tres novelas aquí analizadas se develan los procesos de la historia social y literaria.

Realizando un enfoque en, la crítica literaria, que ha perfilado en considerables contornos al escritor chileno Roberto Bolaño Ávalos (Santiago de Chile, 28 de abril de 1953-Barcelona, 15 de julio de 2003): aventurero, perseverante, desafiante, estoico, autor de culto, amante del cine de ciencia ficción, polémico, autodidacta, vigilante en un camping catalán, vendedor de bisutería en Europa, hurtador de buenos libros, mirada de periodista, poeta y narrador. Entre todos estos perfiles sobresale su radicalidad estética, política y ética tan insobornable como irrevocable. Su infancia transcurre en Valparaíso y Viña del Mar, siendo un escolar con dislexia e hijo de un camionero y boxeador, León Bolaño, y de una profesora, Victoria Ávalos, así como nieto de un militar. A

${ }^{1}$ Sobre este género tan joven y para poder apreciar la "escrilectura" del hipertexto, Anja Rau (2003) señala: "La crítica celebra la narración hipertextual como el resultado de la evolución del texto impreso y como la materialización ideal de la teoría literaria contemporánea, o, por el contrario, la condena por su (supuesta) carencia de calidad literaria [...]. También son representaciones de la vida contemporánea que, aunque al principio puedan resultar difíciles de leer, son, curiosamente, unos textos que resultan aceptables y amenos para los lectores de hoy" (129). 
los 15 años emigra hacia la ciudad de México, marcado por el movimiento estudiantil de 1968 que años más tarde se mostraría en su novela Amuleto $^{2}$ (1999). Inclusive, el supuesto teórico principal, nos indica que el territorio mexicano es la expansiva disparidad de la oscuridad que embarga a todo el continente hispanoamericano.

La ciudad se dibuja en la obra literaria de Bolaño a partir de recorridos y de rutas fracturadas, lo que obliga al lector a desplazarse en distintas direcciones de lectura, en las cuales se funden diversos elementos socioculturales: la crítica a la sociedad moderna pero también a la crisis de las ideologías; las ironías sobre las tradiciones morales y la caricaturización sobre los estereotipos sociales. En términos de estética narrativa la construcción de estos desplazamientos (efecto que se repite de manera intermitente en varios libros de nuestro autor) ha sido definida por la teoría literaria como hipertextos.

Tal es la obsesión de los territorios proyectados a través del film en Bolaño, para satisfacer un cierto deseo de denuncia de la urbe, la cual sus narraciones han rememorado en condiciones ínfimas que dan un salto temporal, del pasado al futuro. En una atmósfera urbana. Por lo tanto, se incorporan preguntas de abstracción tipificadora a partir de la obra bolañiana: ¿Cómo traza las fronteras entre el cine y la narrativa? ¿Se confina a reconstruir como auténtica la historia contemporánea por medio del cine nostálgico y en retrospectiva? ¿Cómo el pensamiento occidental puede devaluar ontológicamente la imagen de

${ }^{2}$ Bajo este trasfondo, se narra desde la postura de un espectador de cine, un hecho cultural mexicano de gran repercusión política y social. La expresión, "Soldado no dispares, tú también eres pueblo", enmarcará aquella noche del 18 de septiembre de 1968, en la cual quedó atrapada Auxilio, protagonista de Amuleto y quien relata el suceso de la Universidad Nacional Autónoma de México cuando fue ocupada por el ejército. Históricamente este hecho constituyó la culminación de una serie de agresiones a las preparatorias y facultades de la UNAM, por parte de los miembros del Movimiento Universitario de Renovadora Orientación (MURO) y los porros financiados por funcionarios estatales y universitarios. La ocupación de Ciudad Universitaria provocó que el movimiento estudiantil se dividiera, por una parte el Consejo Nacional de Huelga comenzó a ceder ante el temor a nuevas represalias, mientras que los radicales decidieron pasar a la acción directa y enfrentar a las fuerzas gubernamentales y días después fue ocupado el casco de Santo Tomás y otros planteles educativos, mientras que brigadas universitarias eran perseguidas por toda la ciudad. 
la mujer a partir de los imaginarios simbólicos? En conclusión, ¿Cómo construye la imagen en los imaginarios simbólicos nuestro autor?

También, a partir de las interrogantes, se procede a unificar términos técnicos. Esto ha implicado la sustitución del espacio escénico por el espacio visual; es decir, existe un terreno abonado que nos genera la imagen asociada, entendiendo el concepto a partir de la disertación de Luz Aurora Pimentel (2001). Permite entender, "Lo que Leguern llama imagen asociada es para Ricoeur el momento icónico de la metáfora, en ambos se hace hincapié en el efecto de sentido sensorial, y con mucha frecuencia visual, que produce la metáfora" (95). Esto es, emplear métodos que ciñen el aspecto verbal y la interacción cognoscitiva de la ciudad violentada. Así lo evidencia Bolaño para la definición de sus protagonistas en las tres obras que seleccionamos, la metáfora entra de golpe y encripta mediante iconografías que son repasadas lentamente, el doble discurso de lo que existe. Aclarando que, sólo se han recogido imágenes no secuenciales, pero sí las más representativas para el presente análisis porque es la estructura del celuloide bolañiano: no secuencial, no lineal y discontinua. En suma, abordaremos cuadros polisecuenciales. Comenzamos con Los detectives salvajes así lo vemos en el diario de Juan García Madero, fechado para el día 21 de enero, donde se suma perenemente el espacio del desierto como el rollo fílmico donde se reescribirá palimpsésticamente poco a poco el mal. A su vez, parece ser una cinta surrealista:

Yo soy el jinete de Sonora, le dije de golpe y sin venir a cuento. En realidad nunca he estado en Sonora. Ella se rió y así hubiéramos podido seguir de plática durante un buen rato, pero se tuvo que ir a atender una mesa. Brígida, en cambio, sí que estaba y cuando ya iba por mi segundo tequila se acercó y me preguntó qué pasaba. Brígida es una mujer de rostro ceñudo, melancólico, ofendido. La imagen que tenía de ella era distinta, pero aquella vez estaba borracho y ahora no. (17) 
Bolaño es un narrador/espectador que con base a su experiencia personal: la diáspora de vida, realiza propuestas teóricas para la recepción narrativa que permita empatizar con el lector, adoptando una postura cinematográfica básica, como señala Lauro Zavala en su Manual de análisis narrativo: "el resto es un mapa de los códigos, es decir, del cine moderno y también del cine contemporáneo" (18). La idea fundamental aquí, es la exposición de una época; propone evidenciar la crisis de la ciudad a partir del proceso industrial que es el puzzle de la intertextualidad posmoderna, puesto que la obra de 2666 es el ascenso de situaciones puramente ópticas y sonoras, aunque el sonido sea sinestésico; provocando que en todos los intérpretes bolañianos se relaten estas imágenes sensoriomotrices. Para todos los personajes, todas las ciudades son lo mismo: "Barrios que vagamente recordaba de los cuentos de Chesterton pero que ya nada tenían que ver con Chesterton aunque la sombra del padre Brown aún perdurara en ellos, de una forma no confesional, dijo Morini, como si pretendiera desdramatizar hasta el hueso su errancia solitaria por la ciudad" (62).

Por otra parte, el hipertexto ${ }^{3}$ aporta los recursos verbales para el estudio del funcionamiento del texto literario, como signo cultural en la lectura del presente trabajo. El hipertexto permite leer los sistemas de signos, sistemas naturales, codificados y culturales, sobre todo para la invención urbanística de Bolaño. Esa estructura del texto que nos transporta a las historias relatadas por el escritor chileno, pero que es el itinerario cotidiano del fin de siglo, en donde todo se aglomera. De ahí que la pregunta por los imaginarios culturales que circunscriben la vida en la posmodernidad y es en este contexto, una respuesta con base al sociólogo francés, Jean Baudrillard, quien ha trabajado esta noción desde las nuevas retóricas de la postmodernidad adecuándolo a la textualidad y al discurso excéntrico en donde el simulacro, lo inaprehensible y lo sintético de

${ }^{3}$ Sigo el concepto abordado por Gerard Genette quien postula en Palimpsestos (1972), a toda aquella relación que tiene un texto, B (hipertexto) con uno anterior A (hipotexto). Genette señalaba que el orden podría ser distinto, puesto que B no se refiera en lo absoluto de A, pero que no podría existir sin A. El teórico francés también lo llamó como transformación, puesto que evoca explícitamente, sin necesariamente hablar de él y aludirlo. 
nuestra condición humana se desplaza de forma paralela a la mutación que ha sufrido la escritura, herramienta que ha permitido al hombre tener una relación con la memoria. Todo escrito siempre ha residido sobre una superficie física, por eso se requiere valorizar el ordenamiento ficcional respetando el funcionamiento actancial. Baudrillard bajo esa mirada intuitiva la ha denominado como una era de lo táctil a lo digital, la que nos ocupa como la subjetividad de Bolaño que obra como fuerza entrópica y revuelve el continuo narrativo. En este caso, a partir de la modernidad, como una cultura letrada, dando ejemplos de la sociocrítica cinematográfica como sustento semántico en la trama de los tres textos; reducidos a un proceso mental y visual, la triada bolañiana ilustra la interacción entre instancias diferentes — cultura letrada, cultura del vacío, cultura industrializadapara asociarse en una realidad semiótica. Todo lo anterior desemboca en los relatos de Putas asesinas, pues si la modernidad comenzó con la nueva galaxiavideo, la posmodernidad abrió con la cosificación de la mujer, de la nueva ola de la seducción videomática que impulsó a estrellas, que más tarde serían pulverizadas ante el estallido de la industria pornográfica. En el cuento "Prefiguración de Lalo Cura", el protagonista entreteje su historia de vida a la par que relata la pérdida del aura de las estrellas y toda la deshumanización del cine que se reescribió en los márgenes de la posmodernidad:

A mi padre lo llamaban el Cura y así fue como mi madre me inscribió en el registro civil. Todo legal. Olegario Cura. Hasta fui bautizado en la fe católica. Mi madre, sin duda, era una soñadora. Se llamaba Connie Sánchez y si ustedes fueran menos jóvenes y más viciosos su nombre no les resultaría extraño. Fue una de las estrellas de la Productora Cinematográfica Olimpo [...]. La Productora Cinematográfica Olimpo se dedicaba a las películas pornográficas y aunque el negocio era semiilegal y el ambiente francamente hostil la empresa no se hundió hasta mediados los ochenta. El responsable fue un alemán polifacético, Helmut Bittrich, capaz de ejercer de gerente, director, escenógrafo, músico, relaciones 
públicas y ocasional matón de la productora. [...]. Si se toman la molestia lo pueden ver haciendo de mirón, de maestro de escuela o de espía en el seminario, siempre en un discreto segundo plano. [...]. El chalet de las películas. La casa de la soledad que luego se convirtió en la casa del crimen, en una zona perdida, llena de arboledas y zarzas. (43)

El soporte básico para las argumentaciones bolañianas, consiste en el cine como otro texto canónico de la teoría hipertextual; ver es buscar el significado que el autor quiere dar a la obra, a la sociedad posmoderna. En el cine existe la crisis, que siempre depende de la causalidad, del desequilibrio entre las causas y los efectos que azotan a sus personajes, y encuentran, o no, su solución en un reajuste de las causas, pero los orígenes son los que se borran y se vuelven ilegibles, dejando su sitio a una intensificación de ciudad habitada por una yuxtaposición llamada posmoderna. En Putas asesinas, el personaje hipotextual de B - juego semántico de Bolaño-Belano — relata la nostalgia como una de las características con las que expone la transición entre la modernidad y la posmodernidad; implícitamente, el cine es una especie de espacio amplificado que otorga un referente extratextual para convertirse en el no-lugar ${ }^{4}$ de las imágenes ópticas, entendiéndose este concepto como las instalaciones necesarias para el tráfico precipitado de personas y bienes:

Durante los dos días siguientes B se dedica a vagar por las calles de París. A veces llega hasta las puertas de un museo, pero nunca entra. A veces llega hasta las puertas de un cine y durante largo rato se queda contemplando las fotografías y luego se va. Compra libros que hojea y no termina nunca de leer. Come en restaurantes desconocidos y las sobremesas son largas, como si en vez de estar en París estuviera en el

\footnotetext{
${ }^{4}$ Con esta afirmación me refiero a la hipótesis defendida por el antropólogo Marc Augé puesto que la sobremodernidad es productora de no lugares, los cuales operan como espacios que no son en sí lugares antropológicos y que, contrariamente a la modernidad baudeleriana, no integran los lugares antiguos y que entran exclusivamente a los llamados "lugares memoria".
} 
campo y no tuviera nada mejor que hacer que fumar y beber infusiones de manzanilla. (Bolaño, Putas 85)

Sin embargo, en Putas asesinas, Bolaño retoma la noción de la pérdida del aura en las fotografías por la reproducción técnica de la que habla Walter Benjamin (2003), puesto que la multiplicidad de la imagen elimina su autenticidad; es decir, existe una develación histórica-nostálgica por el pasado, puesto que las fotos son el hálito que representan el viaje al pasado. Asimismo, nuestro autor es un antropólogo cultural del imaginario simbólico, puesto que ontológicamente la fotografía ha desempeñado un papel muy importante como herramienta de investigación en la antropología desde su aparición en el siglo XIX. Además, la fotografía y la antropología mantienen una relación estrecha; ya que la acción de captar una imagen verifica y cosifica la observación antropológica. Posteriormente, en el siglo XX, su empleo se proyectó como herramienta y método de investigación; tal es el caso que sirvió para simbolizar una representación.

En el escritor chileno, el valor del culto de la imagen tiene su valía a partir de la rememoración de una ciudad, (porque ésta se configura por imágenes) y su belle époque se va desvalorizando, como consecuencia del proceso industrial. Desde luego, en el cuento que abre a Putas asesinas, titulado "El ojo Silva" se acumula una obsesión, la fotografía. El narrador (Arturo Belano) es un viajero que deambula por las ciudades de Buenos Aires y el D.F. después de su salida de Chile, cuatro meses después tras el golpe en enero de 1974. A su vez sobresale otro personaje denominado como el Ojo Silva, homosexual y fotógrafo de profesión, quien describe la problemática de un ser que, a partir de entonces, se convertirá en un exiliado. Emerge una nueva forma de realidad, supuestamente disgregadora, errante u oscilante, que maniobra por bloques, pero en donde se capta por el ojo-lente de Silva el horror del mundo. "El ojo Silva" es el espectador en el film, que representa plenamente al Infrarrealismo, (movimiento poético que 
Bolaño fundó en 1975, como parte de todos los ismos en América), y ese será el celuloide precursor: films de vagabundeos.

Mauricio Silva, llamado el Ojo, cuenta una mezquina historia a través de la utilización del plano-secuencia, en la que se vio implicado cuando fue a realizar un reportaje a la India, lugar en el que descubrió un prostíbulo donde la pedofilia se argumentaba mediante evidencias religiosas. Los "letra-heridos"5 son hipertextos en los textos de Bolaño, "El Ojo Silva" es la imagen-hecho 6 , también concatena una diégesis de violencia y ternura, coacción y reducción de lo real admisible. Además, rememora desde el inicio un contexto latinoamericano; es decir, desde el párrafo inicial el protagonista refiere su constante lucha por huir de la violencia, del verdadero horror, pero del nadie puede escapar, y advierte, "al menos no nosotros, los nacidos en Latinoamérica en la década de los cincuenta, los que rondábamos los veinte años cuando murió Salvador Allende" (Bolaño, Putas 11). En este sentido, al iluminar estos asuntos, se debe hacer hincapié en que los años cincuenta y sesenta fueron aquellos que más se impusieron en la construcción de lo imaginario, en nuestro autor, y se abre esta fase de recuperación del estudio de la imagen por la imagen. En Putas asesinas son héroes obsesionados por la posesión de lo visual. La memoria es fílmica, es decir, reproducir una sacralidad individual que permita volver a escribir un nuevo texto:

Así que el primer reportaje había consistido en fotos donde se vislumbraban casas coloniales, jardines derruidos, restaurantes de todo tipo, con predominio más bien del restaurante canalla o del restaurante de familias que parecían canallas y sólo eran indias, y también fotos del extrarradio, las zonas verdaderamente pobres, y luego el campo y las vías de comunicación, carreteras, empalmes ferroviarios, autobuses y trenes

\footnotetext{
${ }^{5}$ Con este término me refiero al acuñado por Mihály Des, quien lo define como la obsesión por la lectura, la literatura presentada como forma de vida y detonante de historias. (Des 2002).

${ }^{6}$ En el capítulo uno de La imagen-tiempo Estudios sobre cine 2, Gilles Deleuze recupera el concepto propuesto a partir de André Bazin ya que el neorrealismo producía un "plus de realidad".
} 
que entraban y salían de la ciudad, sin olvidar la naturaleza como en estado latente, una hibernación ajena al concepto de hibernación occidental, árboles distintos de los árboles europeos, ríos y riachuelos, campos sembrados o secos, el territorio de los santos, dijo el Ojo. (Bolaño 17)

La creación del primer arquetipo de personaje bolañiano, el viajero como símbolo que recoge la totalidad de los actos de violencia dentro de una colectividad social, se encuentra estrechamente relacionado con el universo poético. A partir de rememorar el pasado, vinculado con la cotidianeidad, este paradigma aparece de forma constante en la narrativa del chileno, lo cual alude a los principios de la geopoética de Gastón Bachelard en La poética del espacio, puesto que el territorio en que se ve a los personajes es siempre un espacio representado, no un espacio real, pero en Bolaño los lugares encubren a la posmodernidad. Es por ello, en el espacio cambiante de la ciudad se recoge el término propuesto por Bachelard de "imagen" que se construye en los personajes bolañianos a partir de la errancia. Nos situamos en el presente del retrato bajo una filosofía de vida que es la poesía, como ontología que a su vez es un apego de la imagen aislada; provocando los perfiles de la gran ciudad que involucra un relato muy detallado de la violencia en América Latina.

De tal forma, hay que recordar que la palabra símbolo deriva del griego $\sigma v \mu \beta \alpha \lambda \lambda \varepsilon \imath v$, que significa "juntar". Por lo tanto, en este artículo se ha decidido realizar un abordaje metodológico desde la hermenéutica, específicamente, para comprender la desaparición del símbolo, o en este caso, a su deconstrucción. Aunque Abbagnano propuso "La existencia del vacío es uno de los teoremas fundamentales de la concepción del espacio como continente de los objetos. Leibniz habló del vacío de formas (vacuum formarum) que existiría si no hubieran sustancias capaces de todos los grados de percepción, sean éstas inferiores, sean superiores a los hombres" (Garbuno, La estética 41). Entiéndase que emprendo el símbolo como "vacío metafísico"; es decir, bajo este panorama 
se acarrea, por consiguiente, una vida urbana que está circunscrita por las altas esferas sociales y el pensamiento de la época, puesto que los puntos estratégicos de una ciudad se proyectan a partir de su significado sociológico, que en cualquier caso viene determinado por la familiaridad de los personajes con el lugar. Sin embargo hay señales en la narrativa bolañiana en las cuales tanto la sociedad, como los errabundos - e incluso el vacío vital- generan una sensación contemporánea y, también, la necesidad de denuncia. Será ahí donde Bolaño establezca un vínculo regenerador con el mundo primigenio.

Precisamente, estos grandes conceptos, espacio/tiempo son los dominantes de lo imaginario urbano, parten del mal aunque sean nombrados de otra forma, siempre presentes en las tres obras: "dictadura", "violencia", "submundo de la prostitución", "pedofilia", donde observamos que las portentosas imágenes del siglo XX exigen atención como concepciones del mundo y de la vida. La hipótesis que aquí se sostiene es que, Bolaño desarrolla toda su narrativa desde el aura totalizadora de la imagen del vacío, Aquí, la "metarrepresentación” del autor es auxiliada por el cine y la fotografía, ésta última con base a Baudrillard en $L a$ transparencia del mal, la fotografía muestra el mundo de acuerdo con la visión del sujeto (27).

En las imágenes de nuestro escritor chileno está todo lo informatizable, eso significa que es el atajo de la cognición valorativa de la sociedad y su problemática. Este reflejo dominante, junto a lo señalado por el sociólogo francés, es modificado por la imagen técnica, en este caso el cine; es decir, que toda acción que quiera ser filmada, quizá su deseo intrínseco no persiga confluir en la memoria, pero se tornará eternamente reproductible. Por lo tanto, respondiendo a una de nuestras preguntas básicas de investigación ¿Cómo se traza las fronteras entre el cine y la narrativa? Dando una hipótesis conceptual en Bolaño, ofrecido desde la fotografía como la imagen más pura cuando sus personajes persiguen a sus ídolos/escritores y todas las formas restantes de la imagen son para denunciar una condición en America Latina; provocando la denuncia en varios cuentos de Putas asesinas, "Todas las ciudades son la misma ciudad", todas las urbes sufren 
de los mismo vacíos. La posmodernidad no es un progreso, la génesis de la historia radica justamente con la fragmentación o la instantaneidad artificial baudrilleana (74).

En Bolaño, el texto se aborda siempre como un filme de seducción sutil, lo transparente del mal radica en hacer eco de los obstáculos epistemológicos, y la pureza se dirige hacia los mismos horizontes que mantienen una trayectoria cultural en expansión, la hipermodernidad. Es notorio el palimpsesto como técnica discursiva con base en Genette, para reescribir un escenario también apoyado más allá del principio de la realidad. Es una obviedad remarcar la preferencia del autor por el cine detectivesco y el cine de ficción, donde se escriben los planos, se fragmenta las secuencias y los personajes. Ocurre que lo que Bolaño comenzó usando como recurso didáctico, acabó transformándose en un intento de conexión entre narrador y palimpsesto, porque se necesita hablar y mostrarse hablando, mostrar y mostrarme mostrando. Además, las tres obras se organizan con una minuciosidad raramente conseguida por otro tipo de cine, alrededor de un narrador abierto. Los protagonistas son hipertextos desde la secuencia de créditos que más adelante reconoceremos en otra narración que señala su presencia. Todos ellos tienen vacíos que se vierten en los espacios urbanos y serán el tratamiento de las situaciones-límite en todas sus obras, que las traza en paisajes deshumanizados. En efecto, si para Gilbert Durand la historia de la censura de lo imaginario se esboza a partir de los cánones establecidos por la cultura occidental (mito, arte y pensamiento religioso), en Bolaño, el imaginario es la significación de la conciencia simbólica.

\section{El hipertexto y la ciudad como trayecto antropológico de no lugar}

Una de las particularidades más relevantes en cualquiera de las obras de Bolaño es la invitación a la observación de algunos filmes clásicos por una parte; y por la otra, desvelan un texto cultural simbólicamente legible. En El balido de la 
oveja negra: la obra de Roberto Bolaño en el marco de la nueva narrativa chilena, Patricia Poblete (2006), señala características del séptimo arte dentro de la narrativa bolañiana, lo que se convierte más que un crisol imaginario del relato, puesto que "la recurrencia a la estética fragmentaria de la fotografía y al movimiento vertiginoso del cine ayuda a crear esta sensación de irrealidad en esta obra. En ambos casos, la mirada está mediatizada por el lente, y éste bien puede estar materializando la segunda conciencia con la que se vive el Apocalipsis" (177). Con referencia a esta condición, y más allá de dicho carácter rupturista, son los espacios y los protagonistas los que se entrelazan en su escritura conformando una "mise en scene". Asimismo, realizando una mirada a los escritos de Bolaño, desde su juventud, cuando era residente en México, se podrá comprobar su afectividad por el cine, sus historias se entretejen y son una puesta en escena que más que teatral, apuntalan hacia una reconfiguración del celuloide, con sus límites que tienen como telón de fondo no sólo las masacres dictatoriales y el duelo irresuelto ante sus muertes en las tres obras señaladas, sino también una modalidad de existencia caracterizada por la disolución posmoderna, una ausencia de felicidad, el mal cotidiano que define a los tiempos desastrosos y que experimenta la vida como trauma en donde también cine y literatura van de la mano. En el imaginario cultural de nuestro autor se lee: "Los latinoamericanos no son nadie en Europa, se desconoce su realidad, sus paisajes son confundidos con típicos paisajes del cine hollywoodiense" (Bolaño, Los detectives 12). Pero este discurso es de progreso, la literatura está incrustada en su obsesión por el cine y para perfilar al lector hacia una psicología literaria, de nuevo, el escritor chileno nos reitera: "Oliverio Girondo encontrará su lugar como escritor juvenil en el año 2099. Roberto Arlt verá toda su obra llevada al cine en el año 2102. Adolfo Bioy Casares verá toda su obra llevada al cine en el año 2105" (Bolaño, Putas 64).

Desde esta lectura, hemos mencionado anteriormente que el hipertexto es empleado por Bolaño en sus narraciones — una historia nos remite a otra-, pero también entraña una manera de entender la vida, la realidad y la representación de lo que aquí se presenta como hipótesis de estudio: una visión posmoderna del 
mundo. En realidad, nos sentimos partícipes de la heterogénea multiplicidad, por lo tanto se nos propone leer este discurso desde la "fragmentación" que opera como un mural de citas o bajo el término de "cámara de ecos", donde la hipertextualidad se hace explícita (Barthes 85). Sobre esta fragmentación (que es la fase de montaje en el cine), y cámara de ecos, en Los detectives salvajes se plantea un juego de voces que crean estructuras narrativas y múltiples. La textura del filme aquí se convierte en palimpsesto, un documento escrito por varias voces, en este caso, los poetas Infrarrealistas construyen diálogos sobre el real visceralismo ${ }^{7}$, un fundamento de historias diseminadas, de introspecciones ensoñadoras y entrelazadas. En un primer plano, las historias están fusionadas con motivo de la búsqueda de la poeta estridentista Cesárea Tinajero y, en una percepción más general, de la generación de poetas real visceralistas de México D.F. —en particular de Ulises Lima y Arturo Belano- - Para la red de historias tiende a proponer un modelo de lectura enfocado en la fragmentación de las historias como efecto directo del uso de la digresión.

El texto rector de Los detectives salvajes emplea diferentes técnicas narrativas por lo que su presentación es de una no linealidad externa que se asemeja al acto de ir al cine. El discurso comienza con una distribución a modo de diario por parte de su protagonista, Juan García Madero, pero también presenta los personajes que formarán parte del grupo del realismo visceral. García Madero, un joven de 17 años estudiante de derecho funciona a su vez, como forma matriz de la imaginación simbólica para el esclarecimiento del infrarrealismo ${ }^{8}$; él es quien enriquece, afina y aporta a sus epígonos. Las relaciones de los personajes se

${ }^{7}$ Pablo Oyarzún (2009), señala que el Infrarrealismo fue más que una institución poética pero, además resulta claro ser una cámara de ecos en donde se incorpora: "el conjunto de dispositivos protectores bajo los cuales se ampara y explaya la poesía en nuestra cultura”. (Oyarzún 322).

${ }^{8}$ Recordemos este concepto ampliamente compartido por los críticos y estudiosos de Bolaño. Por su parte, el movimiento Infrarrealista ha sido estudiado por la periodista y licenciada en Humanidades, Montserrat Madariaga Caro bajo el título, Bolaño Infra, 1975-1977. Los años que inspiraron Los detectives salvajes. La historia de la evolución narrativa de nuestro autor estará claramente marcada a partir de Los detectives salvajes, puesto que, "más que un mapa de lecturas: es también el largo epitafio prematuro de una generación que vio derrumbarse sus ideales a una edad en que debieron haberlos estado viviendo, y es también una pieza de puzzle de la obra completa de que Bolaño quiso resaltar el canon literario que él siguió". (Madariaga 13). 
mantienen habituales y la diégesis contiene a los mismos interlocutores. En esta primera parte, en el proceso del enunciado, sus puntos se entrelazarán a través del concepto detallado de lo que se denomina como realismo visceral y los real visceralistas, por lo que el relato narrado gira exclusivamente alrededor de ellos. Dicho apartado de la obra culmina con una escena clave en la que se encuentra Lupe, Arturo Belano, Ulises Lima y García Madero huyendo de Alberto (el proxeneta de Lupe, quien quería llevársela con él).

Los intentos actuales de ruptura con el texto unilineal en nombre de la multifinalidad (hipertextualidad) muestran en forma implícita o explícita la lucha entre la defensa política y académica del discurso universal, fijo e inamovible, aquello que es el pensamiento único frente al relativismo individual y capaz de establecer sus propios centros o descentrar el discurso establecido. El hipertexto reconfigura la manera en que concebimos los textos y los autores de los propios manuscritos; si bien, el hipertexto coloca en recelo la narración y todas las formas literarias basadas en la linealidad ${ }^{9}$. Sobre esta fase creciente el hipertexto, debe permanecer constantemente en el prolongamiento de su hipotexto; es decir, involucra a desconfiar de las ideas de trama e hilo narrativo que se propone. Recordemos que Aristóteles en su libro de Poética aborda la linealidad proponiéndola como secuencia fija que desempeña un papel fundamental en la trama. Aunque para el hipertexto dicha "secuencia fija" (empleada también en el cine) será uno de los tantos caminos que habrán de seguirse.

Por otra parte, la teoría literaria ha ofrecido diversos usos retóricos al hipertexto, que se ha podido llamar y clasificar por María José Vega en su edición de Literatura hipertextual y teoría literaria como hiperliteratura, la narrativa hipertextual, el hiperdrama o la hiperpoesía (2003). Efectivamente, el hipertexto permite arribar a nuestra propia noción para construir un discurso definitivo, aunque de la mano del lector, por un autor que brinda diversas ramas del mismo

${ }^{9}$ Dentro del concepto de linealidad existe una confusión frecuente, dado que se le considera como una propiedad de todo proceso semiótico o de toda sintagmática. Greimas se apoya en Louis Trolle Hjelmslev para ampliar esta idea en donde pone en manifiesto la oposición de los ejes paradigmático y sintagmático, bajo esta perspectiva, se observa que la semiótica plenaria contiene una manifestación espacial que no necesariamente es lineal. 
árbol; es decir, recolectar voces ficticias que Bolaño expone y vincula con la realidad tanto literaria como extratextual a través de un diálogo abierto vinculado con el devenir cultural de Latinoamérica y su relación con el mundo. Al mismo tiempo, se cotejan figuras y momentos clave de las letras e historia de nuestra lengua castellana. Por otro lado, el hipertexto bolañiano aprecia la verdad y persigue caminos hipertextuales que también son mapas con secuencias finales como el cine.

Ahora bien, todo lo que Bolaño describe, imaginario sin duda, acerca de la sociedad buena y de la sociedad mala, su introspección que pasa a formar los efectos culturales del tiempo referenciado, exponiendo el mundo petrificado, es uno de los elementos estructurales de sus historias. Recordemos que antes, Jacques Lacan propuso la realidad humana regida bajo tres estratos: lo simbólico, lo real y lo imaginario. La inflexión que hace Bolaño es a partir de ciertos diálogos que siguen un itinerario de cine, de tal forma que, la patología de sus protagonistas es en relación con cierto orden donde desdobla el inconsciente colectivo y el sistema narrativo, el cual opera bajo otro orden tríadico: real, simbólico e imaginario; siguiendo la enseñanza lacaniana donde lo simbólico es el nexo que articula cuerpo y alma. Por esta razón, Jacques Lacan en Escritos 2 (1995), advertía que el alma era una ciega lúcida, puesto que lee su propia naturaleza en los arquetipos que el mundo le refleja (680). Del mismo modo, Bolaño no sólo encontró en la palabra escrita la herramienta perfecta para expresarse con los lectores, sino también pudo recrear escenas en las cuales recurrió al cine como el reflejo de la vida misma. En Los detectives salvajes y en 2666 se proyecta a personajes que observan en sus televisores películas que en realidad eran las predilectas de Bolaño: Vengar la sangre (The Limey), del director Steven Soderbergh (Estados Unidos, 1999), Andrei Rublev, de Andrei Tarkovski (Rusia, 1966) y Ringu, (Japón, 1998). No es casualidad que los personajes de Bolaño dediquen páginas enteras a relatar películas, dado que si conectamos bajo el esquema lacaniano, entendamos el imaginario simbólico latinoamericano que importa a partir de lo real. Detengámonos aquí, el sujeto se 
condiciona a partir de filmes negros donde se proyecta de nuevo la violencia, la gnoseología de Bolaño es impulsada por el deseo de justificar las representaciones del mal como símbolo de la ruina de la visión del mundo de su época.

Un detallado análisis del proceso del vacío lo ocupa el espacio erótico/pecado. Por lo tanto, es conveniente abordar la zona más angustiosa en la narrativa del chileno, "Prefiguración de Lalo Cura" de Putas asesinas donde aparece la concatenación de la crisis de la idea de la vacuidad que entraña la idea de progreso. Olegario Cura Expósito también será un personaje hipertextual en 2666. Por esta razón, se debe recalcar que a través de este nombre se hace un juego fonético-semiótico donde la imagen persigue una directriz de atrofia hacia una simulación indefinida: mal/posmodernidad. Él es hijo de una actriz porno, y se convierte paradójicamente en un asesino a sueldo y policía-; es decir, esa misma "falta de nutrición" en el personaje se gesta desde el cuento de Putas asesinas. Lalo Cura es el más representativo de esta genealogía bolañiana, de esa falta de cimentación de identidad latente en Latinoamérica, la construcción del imaginario simbólico de la ausencia paterna - Lalo Cura en ambas narraciones es huérfano ${ }^{10}$ _ puesto que él es el emblema de una cultura en la que "no se ha abolido en una idealidad trascendente sino en una estetización general de la vida cotidiana, ha desaparecido en favor de una circulación pura de las imágenes, en una transestética de la banalidad" (Baudrillard, La transparencia 6) Olegario es la simulación de un buen ciudadano (cuya curvatura es fingir lo que no se tiene) y el desarraigo sistemático de no pertenecer a ningún lugar; en pocas palabras es la indiferencia pura del habitante del vacío. En realidad, Olegario Cura es el

${ }^{10}$ Alberto Bejarano (2010), en "República de Expósitos. Genealogías de la orfandad en 2666 de Roberto Bolaño", ha examinado a la orfandad como común denominador que simboliza Olegario en América Latina, a través de ambas narraciones pero en particular en 2666, en "La parte de los crímenes", en donde construye al personaje degradado, entre la simulación y la indiferencia pura del mundo posmoderno, cuando arriba a la ciudad industrial: Lalo Cura se convierte en el único policía mexicano que investiga los crímenes con alguna pericia, aprendida de manera más autodidacta. Su genealogía marca la manera cómo se enfrenta a los cadáveres de las muertas de Santa Teresa. [...]. Hijo de María Expósito y descendiente de toda una saga de mujeres violadas desde 1865 [...].Lalo Cura no es un hombre duro. De hecho, él es el único miembro de su familia que no nació como producto de una violación en ninguna de las dos versiones que fabrica Bolaño (31-41). 
significante opaco de personalidad muda; es decir, encara con el silencio la autodestrucción, como negación del habla y del lenguaje colectivo. Lalo funciona como un vacío de sentido, o en todo caso se entendería del sentido del sin-sentido que señala Gilles Deleuze en su Lógica del sentido (102).

Aquí, los trece cuentos pertenecientes a Putas asesinas son la imagencristal $^{11}$ en relación a otras imágenes, dejando patente una extensa preocupación por el futuro. El tiempo en el cristal contiene una discrepancia a partir de dos movimientos, pero uno de los dos será el representante del futuro y de la libertad, a término de salir del cristal. Justamente lo real será creado, al mismo tiempo, la eterna remisión de lo actual y lo virtual se desaparece entre el presente y lo pasado (Deleuze 1985). Aquí, la imagen-cristal constituye: “el sexo-máquina, el sexo abandonado al juego de lo que sea, el sexo alta fidelidad, ese es el vector humorístico. Prevalece entonces la pornografía como sexo tecnológico y el objeto como tecnología porno. Como siempre, el estadio humorístico designa el estadio último del proceso de substancialización: lo porno liquida la profundidad del espacio erótico" (Lipovetsky, La era del vacío 131). Es esta la geografía social expuesta en el cuento "Prefiguración de Lalo Cura":

Película profunda como pocas, solía recordar Doris, de esa vil manera acabamos las artistas de cine porno, devoradas por fulanos insensibles después de ser usadas sin descanso ni piedad. Parece que Bittrich hizo esa película para competir con las cintas de porno caníbal que empezaron a causar sensación en aquella época. Pero a poco que uno la vea con algo de atención se dará cuenta de que lo importante es el Pajarito Gómez sentado en la timba. El Pajarito Gómez, que sabía vibrar desde dentro hasta empotrarse en los ojos del espectador. Un gran actor desperdiciado por la vida, por nuestra vida, amiguitos. Pero ahí están las películas del

${ }^{11}$ Deleuze en La imagen-tiempo. Estudios sobre cine 2, destaca el concepto de "imagen-cristal", la cual contiene una ordenación bipolar o bifaz; es decir, deviene a partir de una aceleración, una fragmentación que constituirán la cara opaca del cristal y le confiere una "transparencia" que es la prueba de lo eterno. 
alemán, todavía impolutas. Y ahí está el Pajarito Gómez sosteniendo esas cartas llenas de polvo, con las manos y el cuello sucios, los párpados eternamente caídos y vibrando sin tomarse un respiro. El Pajarito Gómez, un caso paradigmático en el porno de los ochenta. (Bolaño 105106)

Ciertamente existen diferentes patrones en lo cinematográfico por parte de Bolaño en sus textos. El más notable sería el cine policiaco, el fantástico y el de terror, géneros por los que se inclinó durante su producción narrativa. Sin olvidar que las efigies bolañianas sueñan o llevan a cabo acciones a manera de diversos planos como menciona Lauro Zavala (2010), lo cual a partir de ese momento establece lo que llama como "contrato simbólico"; es decir, mucho tiene que ver el ánimo coyuntural de los protagonistas. Por esta razón, la elección genérica en Los detectives salvajes desde su discurso regente a las crónicas literarias y periodísticas, es la elipsis, los saltos entre el tiempo y el espacio son notorios. El imaginario simbólico de Bolaño apuesta por la percepción-conciencia del vacíoviolencia en la ciudad latinoamericana. Para el escritor, el vacío es la ausencia de sentido, mientras que la nada aparece como la negación de la realidad bajo el aspecto de lo real, donde el espacio urbano soporta la tensión entre espacio positivo y espacio negativo. La narrativa de Bolaño representa, más que los espacios urbanos en sí mismos, una inserción del universo del vacío.

A través del rescate de las películas que privilegian un eje entre narración y film, se advierte una palpable clasificación. Lo imaginario es esa encrucijada de los problemas planteados por el comportamiento del ser humano que Bolaño posee como suma cultural; es decir, establece un imaginario normal y otro patológico desde la antropología augeniana, el cine como no lugar. Las estructuras urbanísticas industriales fueron diseñadas y revelan los lugares, muy diferentes de los que puede apreciar el protagonista viajero en Bolaño. Con ellas se ha pasado al filme individualista de la posmodernidad. Pero son los tres textos proyectados por los recorridos de la ciudad tecnificada, "El pasajero de los no 
lugares sólo encuentra su identidad en el control aduanero, en el peaje o en la caja registradora. Mientras espera, obedece al mismo código que los demás, registra los mismos mensajes, responde a las mismas apelaciones. El espacio del no lugar no crea ni identidad singular ni relación, sino soledad y similitud” (Augé, Los no lugares 106).

Precisamente, es el pensamiento occidental, el que devalúa y cosifica la imagen de la mujer en función del horror y la falsedad posmoderna. En Bolaño, la narración como cine de ficción permite atravesar las ciudades con sus puntos más notables para señalar el símbolo de la muerte; es decir, la imagen del cementerio como signo eficaz de lo ficticio. El autor consagra todo el inconsciente del pensamiento colectivo, pero para esto, realiza una angulación desde los territorios culturales, siendo la obra de 2666 la estructura antropológica final de su imaginario. Definitivamente incorpora una cámara lenta en los espacios de la ciudad, en este caso la ficcionalizada "Santa Teresa". Aquí se ha llegado a la creación de una atmósfera que focaliza la relación entre personaje y lugar. Si Yuri Lotman reconoce que un signo no sólo es portador de un significado, en Bolaño, además tiene que formar parte de un sistema; el actante es parte también de dicho método. La preeminencia del procedimiento semiótico de este teórico reside en examinar la estructura literaria interna, y las relaciones externas entre el texto y el contexto sociocultural que nos ocupa.

Al no ser la literatura exclusivamente un código lingüístico, en el proceso social de producción y percepción, la función del personaje bolañiano es la de ser un representante de manera que en él se conjugan muchos planos y es factible que todas estas tesituras se entrelacen. Los personajes bolañianos encubrirán a su vez, el signo de la posmodernidad, del trotamundos enclavado en la literatura. Aparece la "indolencia" del ciudadano que retrata Bolaño, en 2666, donde los íconos femeninos se adecúan para explorar el pensamiento de los urbanitas y su tiempo puesto que es lo que señala Daniuska González (2008): "la vacía organicidad de los unos en el otro. Se les ha condenado a un espacio socialmente separado, y sus respuestas no se han hecho esperar: mancillan, hieren y asesinan al prójimo, 
porque solo así encuentran el reconocimiento y solo así se levantan la máscara colectiva y aplastante del anonimato" (167). La mujer es el símbolo vacío que encabeza el título de la narrativa, pero también reivindica el valor inaugural de la indolencia, que subraya el carácter hermenéutico de las féminas como engranaje principal de la novela negra. Surge otra cara fractal en el sentido rigurosamente existenciario-temporal del concepto de la ciudad.

En este desplazamiento de figuras por el espacio, la narración de 2666 se conjuga con la urbe como un mundo movilizado hacia un todo que se acoyunta. Como el mismo Néstor García Canclini sostiene en La sociedad sin relato (2010), en donde la indiferencia de los protagonistas bolañianos son los tiempos externos y los tiempos íntimos de los escenarios. Vale decir, es evidente el territorio subjetivo de la megalópolis (ciudades de Latinoamérica, el D.F. y finalizando con Ciudad Juárez, Chihuahua) la cual corresponde a la pérdida del sentido de los límites en los pobladores de la urbe. De modo claro en el discurso opera una permuta que resulta tan problemática como el cambio propuesto para el concepto de ciudad posmoderna que transita hacia otro sentido. Además las categorías indiferencia/vacío ya avasallan disueltas en palabras en un flujo expansivo. Además, en 2666 se hace la referencia también, del cine como no lugar, con 103 referencias en concreto en sus más de 500 cuartillas. Ahí los personajes se entrecruzan para relatar la decadencia de la ciudad. Desde las primeras páginas, en la "Parte de los críticos" todo pulula con base a las necesidades ontológicas de encontrar a su ídolo-escritor (Archimboldi). Por lo tanto, se requiere de un trayecto antropológico de incesante intercambio entre las pulsiones subjetivas del autor y los protagonistas:

Recomendaciones de películas, comentarios desapasionados sobre libros recientes, en fin, una conversación telefónica más bien soporífera o cuando menos desganada pero que Espinoza escuchaba con un raro entusiasmo o con fingido entusiasmo o con cariño, en cualquier caso con civilizado interés, y que Morini desgranaba como si en ello le fuera la 
vida, y a la que seguía, al cabo de dos días o de unas horas, una llamada más o menos en los mismos términos que Espinoza le hacía a Norton, y que ésta le hacía a Pelletier, y que éste devolvía a Morini, para volver a recomenzar, días después, transmutada en un código hiperespecializado, significado y significante en Archimboldi, texto, subtexto y paratexto, reconquista de la territorialidad verbal y corporal en las páginas finales de Bitzius, que para el caso era lo mismo que hablar de cine o de los problemas del departamento de alemán o de las nubes que pasaban incesantes, de la mañana a la noche, por sus respectivas ciudades. (Bolaño 12)

El cine auxilia a narrar la imagen de la ciudad, el no lugar donde se suprimen espacialmente las señales del territorio, las de la identidad para convertirse en un cruce de elementos en movimiento, en este caso, son los personajes los que transforman en espacio violentado al espacio existencial. Lo fundido encadenado es un plano sin corte, se presenta para sustituir suavemente a la figura geométrica de la violencia. La urbe es el no lugar de los vertederos. En resumen, la triada textual (Los detectives salvajes, Putas asesinas y 2666), proyectan la imagen de una realidad urbana periférica demasiado "real" donde lo único que parece dar sentido a la vida es el sinsentido del vacío. Probablemente se hace presente de modo continuo con el signo de la muerte, a través de aspectos muy claros como: asesinatos, robos y exilios, para al final desembocar en una relación de valor espacial con el mundo como cementerio: la urbe vertedero y el discurso literario que se encarga de construir el significado de periferia urbana postmoderna y de este contorno en concreto, el cual deriva a la oposición espacial arraigo/ausencia.

La única dimensión de las ideas vertidas por el escritor sobre este tema, como la vacuidad de la ciudad, o las nuevas morfologías urbanas, están cargadas de una fuerte germinación desde la errancia, por arborescencia narrativa del flujo textual y el cuerpo de sus relatos. Por ello toca organizar la distribución funcional 
de los territorios, realizar el estudio semiológico del lugar, a partir de las dos primeras categorías que hemos señalado: el trayecto y la violencia, las cuales expanden la función generacional de la urbe. Es la visión próxima y plana que induce una participación de los lugares comunes sobre la soledad y la incomunicación.

\section{Las estructuras antropológicas de la ciudad violentada}

La comprensión de las cuestiones epistemológicas en los territorios subjetivos para la composición de la ciudad en Bolaño, arroja la luz sobre los espacios activos del pensamiento; es decir, en este caso, aparecen los protagonistas como excipientes fundamentales que acrecientan una fractalidad para convertirlo todo en uno o volverlo un eslabón de la cadena magnética de la urbe. Y bajo estos signos de realidad, Clifford Geertz señala una refiguración del pensamiento social, donde para entender la textura de la vida interior del individuo, en suma, hay que moverse en torno de su círculo hermenéutico. Se trata pues de lo señalado anteriormente por el antropólogo en La interpretación de las culturas: "las estructuras que lo simbólico trasunta, si bien elusivas, no constituyen milagros ni espejismos, sino hechos tangibles" (10). Es obvia esta deuda de Bolaño con la interpretación de la cultura de símbolos, puesto que nuestro autor desentraña la indiferencia como otra cara fractal del vacío, en donde se narran los procesos de los territorios que ocupa "Santa Teresa" en las coordenadas del espacio social, y es un estado de tremenda e inmensa soledad. Ciudad proto-antropológica como un sistema de bloques donde los personajes se han vaciado objetivamente: sufren más de la ausencia de otro que de una ausencia de sí mismos:

Santa Teresa, esa horrible ciudad, decía Norton, la había hecho pensar. Pensar en un sentido estricto, por primera vez desde hacía años. Es decir: 
se había puesto a pensar en cosas prácticas, reales, tangibles, y también se había puesto a recordar. Pensaba en su familia, en los amigos y en el trabajo, y casi al mismo tiempo recordaba escenas familiares o laborales, escenas en donde los amigos levantaban las copas y brindaban por algo, tal vez por ella, tal vez por alguien que ella había olvidado. Este país es increíble (aquí hacía una digresión, pero sólo en la carta a Espinoza, como si Pelletier no pudiera entenderlo o como si supiera de antemano que ambos iban a cotejar sus respectivas cartas), uno de los mandamases de la cultura, alguien a quien se supone refinado, un escritor que ha llegado a las más altas esferas del gobierno, es apodado, con toda naturalidad, además, el Cerdo, decía, y relacionaba esto, el apodo o la crueldad del apodo o la resignación del apodo, con los hechos delictivos que estaban ocurriendo desde hacía tiempo en Santa Teresa. (Bolaño 90)

La ciudad, en la cual encontramos la modernidad agonizada. La urbe, descrita como un territorio miserable en medio del desierto ${ }^{12}$. El orden del discurso ha sido perturbado por la inserción de los territorios mexicanos: Durango y Gómez Palacio, en donde el símbolo del desierto será el puente hipertextual de la narración cinematográfica de 2666. Aquí, el protagonista propone la pretendida cognoscibilidad de todo lo real, el territorio misterioso, pecaminoso, el que está fuera de la ley; así como la urbe diabólica en donde se aumentan los índices augurales de la crisis de valores del siglo $\mathrm{XX}$.

Por otra parte, el formato panorámico (Cinemascope), que se logra con la visión espectacular de situaciones y paisajes de diversas urbes de Latinoamérica, la cuales se mencionan en 2666 , hasta desembocar con la urbe violentada que

12 A partir de 2666, han sido varios los autores mexicanos que han intentado ir más allá de una literatura sobre "desierto" y violencia contemporánea, provocando "La literatura del norte de México". Con Tierras de Nadie, escritores norteños como Daniel Sada, Eduardo Antonio Parra, David Toscana y Luis Humberto Crosthwaite trataron de "reflexionar sobre esa etiqueta llamada literatura del norte y que con un afán totalmente mercantilista consolidó a una serie de autores que al parecer compartían un proyecto estético. Lo que quisimos es desarticular esa categoría, porque que un autor haya nacido en el norte de ningún modo lo autoriza más que a otro autor a hablar sobre determinados temas como el narcotráfico o el desierto" (Nava, Tierras de nadie 7). 
denuncia los asesinatos de Ciudad Juárez, donde se remarca para instaurar una vez más la posmodernidad aletargada, el autor, tensa mediante imágenes el mundo banal y la problemática ya antes advertida por Nietzsche, en la lucha más despiadada del individuo. También, en las representaciones de la vida contemporánea, se abren nuevos contextos para que el lenguaje efectivamente configure el imago mundi.

La ciudad delimitada por los recorridos antropológicos se encuentra constituida por el símbolo del vacío, expresado a partir de dos signos convergentes: mal y violencia. Por lo tanto, con el arribo de la ciudad industrial, las mujeres jóvenes de Santa Teresa (Ciudad Juárez) se convirtieron en las poseedoras del empleo y del dinero, al contrario de la estructura patriarcal que hasta antes dominaba. El imaginario simbólico deriva en la investigación cultural: 2666 el espacio-imagen del vacío. Simboliza la muerte-orfandad que lleva consigo: las áreas deshabitadas, el desierto y los vertederos. Pero no podemos olvidar que el espacio en la narración siempre propone espacios irreales con el nombre de "basureros" en donde son arrojados los cuerpos, columna vertebral donde desemboca el colapso de la sociedad. Bolaño alude a ella, en los que sus referentes en 2666, son explícitos y reconocidos: "En octubre no apareció ninguna mujer muerta en Santa Teresa, ni en la ciudad ni en el desierto, y las obras para eliminar el basurero clandestino de El Chile se interrumpieron definitivamente. Un periodista de La Tribuna de Santa Teresa que hizo la nota del traslado o demolición del basurero dijo que nunca en toda su vida había visto tanto caos" (116).

Esta cartografía literaria se conforma a través de la irrupción cotidiana de la muerte, que se yuxtapone al espacio urbano. El título de esta última obra, 2666, repica como un código, es lo que la investigadora Kathy Fourez (2015) ha señalado como "El eco sucesivo y sempiterno que se destaca de la sibilante del seis recuerda por onomatopeya no sólo el silbido del peligro viperino, del viento angustioso que barre el desierto del norte de México, sino también un espacio circular vicioso y sin salida, un espacio en el que se vuelve siempre al crimen" 
(5). En repetidas ocasiones por comodidad metodológica Bolaño testimonia el espíritu de la ciudad cuando comienza a ser invisible y cuando, a la par, todas las urbes empiezan a ser iguales; es decir, cuando es cada vez más difícil habitarlas como ciudades y se convierten en megalópolis. Relatos hilados con susurros que atrapan en un mundo inasible como el mal, cuyo presente es una pura ausencia, el pasado presencia de indiferencia, un mundo en el que al parecer, surge con la urbe, en la que se despedazan todas nuestras nociones de tiempo y de espacio desde el hipotexto con el flâneur, símbolo del observador callejero, Arturo Belano, protagonista de Los detectives salvajes y Putas asesinas, por los infinitos “caminos de la fractalidad" de un texto que se despedaza para multiplicarse.

Es en esta armónica integración de universos, y en esta continuidad hacia un proceso de consolidación del vacío, en los que el hipertexto de 2666 se resigna a consignar la muerte donde la imagen de la urbe y el espacio evocan un relato bajo el mismo horizonte. Ahí la operación narrativa de Bolaño es un combate cara a cara con la muerte, pues las diversas historias que se narran en la novela concurren, en un momento u otro como todos esos ríos que van al mismo mar, en la ciudad mexicana de Santa Teresa, la cual funciona como una reproducción de Ciudad Juárez. 2666 es el proceso de despersonalización en donde se aseptiza el vocabulario como lo hace con el corazón de las ciudades, los centros comerciales y la muerte. Todo lo que presenta una connotación de inferioridad, de deformidad, de pasividad, de agresividad debe desaparecer en favor de un lenguaje diáfano, neutro y objetivo, tal es el último estadio de las sociedades individualistas (Lipovetsky 17). La realidad de una urbe posmoderna y plena de la emanación del vacío que produce la muerte de las mujeres en Santa Teresa, así como toda otra serie de atrocidades que se dan en ella, genera un espacio de opresión y un espacio vacío en contraste con el universo del todo. El personaje de Guadalupe Roncal en "La parte de Fate" (el tercer segmento de 2666), advierte: "Nadie presta atención a estos asesinatos, pero en ellos se esconde el secreto del mundo" (Bolaño 217). 
La desesperación infinita y el vacío abren el espacio de la muerte que poco a poco carcome a la ciudad, y es que "Nos hemos acostumbrado a la muerte" (Bolaño 162), frase que actúa como la elegía en la narrativa. Asimismo esta dependencia que establece nuestro autor entre una urbe del norte de México y la muerte que encarna como figura en el espacio proyectado en esta novela es, entonces, una red simbólica: amor, madre, sociedad, mujer, asesinatos. 2666 planea la imagen de los espacios, la presencia de un entorno y de un paisaje mexicano que significa dolor/muerte. Bolaño nos indica que la ciudad de Santa Teresa posee una cartografía de desesperanza; es decir, los asesinatos tipo rituales de niñas y mujeres cifran una destrucción del mundo actual. Dicha obra tiene los dígitos de la muerte en los cuales el autor chileno nos expresa: se está fundando el futuro del mundo; desde México, espacio de la muerte, en donde se proyecta el porvenir de los urbanitas.

En efecto, el símbolo de "666" es el número de la bestia en el Libro de la Revelación, que aún hoy se emplea para evocar las imágenes del mal. Aquí Bolaño combina la crónica periodística y el cuento en cinco historias aparentemente sin conexión subrayando el absurdo de las interacciones urbanas y sociales; éstas últimas aparecen enmarcadas dentro de la crítica sobre la condición industrial más una reflexión urbana sobre la metrópoli. Además la intersección de modos culturales pone la crónica breve al servicio de la hipertextualidad gracias a la cultura que lleva consigo la ciudad tecnificada y sus espacios. El autor utiliza estos lugares para orientar la historia de esta relación y para subrayar las divisiones de clase social que trazan los personajes, en particular las entidades femeninas; provocando que la imagen de la mujer simbolice a todo aquello que muere, pero a su vez, es una forma de estructuralismo figurativo bajo los tratados de la estética moderna.

Surgen con esto varias perspectivas de otredad, encarnadas por los personajes femeninos, quienes en esta situación mostrarían una mayor conciencia de las divisiones internas del yo: un yo descentrado o ausente, imagen que expresa simbólicamente aquello que en realidad se ignora o no se quiere revelar, una 
cultura que encarna los miedos y temores bajo el mito que el gobierno mexicano se niega en revelar: los feminicidios. No hay antídoto para la ciudad violentada, la voz narrativa del escritor chileno comunica desde el principio el colapso de la modernidad en la gran urbe y sus espacios. El resultado es que ambos fragmentos interactúan como patrones basados en el vacío crepuscular donde los no-lugares urbanos tienen más realidad y conexiones que las que nos ofrece lo "visible" del tiempo.

El flujo mismo del imaginario vivo de las sociedades que señala Durand, no es otra cosa más significativa que los laberintos y sus trampas que se ofrecen en las obras que abordamos, por otra parte, establecen una búsqueda detectivesca sin vigencia. Estas indagaciones en vez de encaminarse hacia posibles salidas sólo fecundan más historias, deslazamientos, destierros, exilios, movimientos, perdiciones, maldad, muerte y la imagen del vacío que es silencio cuando se enfrenta ante la opacidad del significante: urbe. El espacio narrativo se desgaja: la violencia y el mal está en potencia en el vacío. En las tres obras, esta dimensión comienza a rebasarse. Esta traída es una sola propuesta de denuncia, pues se introduce un espectáculo contemporáneo que ya tiene espectador: el lector. Bolaño desvía este espacio de inserción original, lo trasforma y lo constituye a su vez en los otros tres textos que simultáneamente analizamos; una dimensión como un movimiento de autofagia, un procedimiento que a su vez anuncia una nueva lectura. Así lo notifican Los detectives salvajes al final de la obra: "En fin, éramos los típicos muchachos latinoamericanos de cuarenta y pocos años que se encuentran en un país africano que está al borde del abismo o del colapso, que para el caso es lo mismo" (553).

Los signos de dichas resquebrajaduras sociales sugieren que se está sufriendo un colapso en los espacios urbanos pues los valores antiguos y eternos colisionan con los actuales. Los personajes intentan restaurar o renacer de aquellos principios, pero sin éxito alguno. El autor construye el imaginario simbólico a través de dos pasos; el primero, es un relato textual del espacio como una metáfora que responde a que dicho lugar no existe como tal; el segundo, 
donde imagen y sentido de los personajes aluden como conciencia del ser en un lugar sin identidad. El Dasein (ser ahî) para Heidegger ocupa a la existencia, en Bolaño es una realidad temática que alcanza también desde la subjetivación, ya que se habilita el abandono del paradigma moderno; quizás esta sea la salida propositiva, o un camino que nos lleve al conocimiento del mundo mediante la realidad y el sujeto. Se hilvana la experiencia urbana de esas ciudades que se desarrollan arquitectónicamente mientras los sujetos culturales son el espectáculo de la nada. La configuración de la imagen de la ciudad conlleva explícitamente el feminicidio en donde se intenta desafiar y denunciar la violencia de la vida cotidiana; las partes desmembradas de cuerpos son sólo la metáfora del colapso moderno:

La última muerta de mayo fue encontrada en las faldas del cerro Estrella, que da nombre a la colonia que lo rodea de forma irregular, como si allí nada pudiera crecer o expandirse sin aristas. Sólo la cara este del cerro da a un paisaje más o menos no edificado. Allí la encontraron. Según el forense, había muerto acuchillada. Presentaba signos inequívocos de violación. Debía de tener unos veinticinco o veintiséis años. (Bolaño 222)

\section{Consideraciones finales}

En conclusión, las tres obras son el cordón umbilical de la obsesión infinita de nuestro autor por presentar los distintos modos de caminar sobre esta urbe a la vez desolada y superpoblada como señala Calvino (1972), "el paisaje invisible que condiciona lo visible" (20). Además, en Bolaño estipular dicha imagen urbanística alcanza su máxima mutabilidad, la cual se torna representable y legible. El discurso de la imagen contribuye a legitimar el fin de la modernidad en la ciudad que a su vez anuncia varios tipos de prácticas sociales con 
recapitulaciones de la representación, reproducción y fijación de la dimensión intertextual que nos ocupa, en términos de lo imaginario, de las nuevas posibilidades simbólicas que denuncian el "debilitamiento" de la sociedad moderna. A su vez, la técnica escritural del cine, en la que se apoya Bolaño para Los detectives salvajes, Putas asesinas y 2666, dirección y hasta de posición del espacio son una constante. La presentación de los personajes es sistemático: interiores vaciados de su sentir, exteriores desérticos, paisajes de lo real y lo imaginario o del sujeto y el objeto.

La intención simbólica/alegórica de Bolaño proyecta el exilio en sus personajes después de la modernidad como promesa utópica de liberación, de su literalidad en continuo desplazamiento hacia la posmodernidad donde la experiencia de la angustia es el desarraigo que proyecta el vacío. La fotografía y el cine son las estructuras antropológicas del imaginario simbólico de la violencia de un nuevo siglo. La ciudad violentada es un símbolo direccionado en múltiples sentidos, en una forma poliédrica y de significación directa a la derrota. Bolaño es el fotógrafo del miedo, de la fascinación por el mal en los espacios latinoamericanos. El desarraigo del hombre -como una de las principales características de la ciudad posmoderna- se basa en el desconocimiento de la herencia de una tradición; es decir, es una voluntad de extirpar sus ideas y sus posibilidades estéticas, las cuales se habían perdido en el camino. Es una "desterritorialización" donde se ejerce una doble dinámica proyectiva, por una parte, los personajes son infelices en cualquier territorio que ocupen y, por otro, los territorios son lugares de deseos que pueden transgredir cualquier connotación realista; en este caso puntual el desarraigo es una representación figurada de lo "identitario". Al desarraigarse, las efigies bolañianas se convierten en figuras huidizas pero que construyen su alteridad con respecto al orden del discurso, ahí mismo se obtiene la máxima significación ideológica: yo soy el otro.

El vacío adquiere un valor palimpséstico, es la compleja red simbólica que engendra las raíces que se reúnen y dispersan desde Los detectives salvajes hasta 2666 para servir como ensambladura entre el nivel simbólico, la lenta evolución y 
el nivel metafórico de la ciudad literaria. El resultado más extraordinario de este nuevo tejido es la intersección ideológica a la que se asiste a partir de la toma de conciencia de las funciones de dicho símbolo en el espacio urbano. Además, la función representativa de los personajes, los coloca como testigos que desarrollan la ciudad representada sobre la base de las evidencias narratológicas del escritor chileno, de tal forma, que se opera el entrecruzamiento: historia, ficción y refiguración del tiempo. Los periodos señalados tienen para Bolaño una continuidad secuencial y progresiva, en la que la transformación de la ciudad moderna a ciudad industrial es la causa de la diáspora de los seres culturales, en sí, hacia una nueva construcción simbólica del vacío.

El discurso subraya lo urbano imaginario para evocar el relato "postindustrial", cuando la urbe se ve alterada y se señala como un espacio vacío a partir de las siluetas "destrozadas" de sus personajes a través de fotografias que hacen voltear a ver. De paso, el cine sirve, aplicado a la teoría narratológica, para programar dichos fotogramas de forma rápida y sucesiva que recrean al movimiento. Asimismo, la ubicación física del palimpsesto urbano se superpone a un espacio representado donde el destinatario/lector obtiene la doble recepción desde donde se dibuja a la lectura nueva de transparencia + concavidad= vacío. El Big bang del imaginario simbólico para América Latina es claro, ya que no existe antídoto para los territorios de la no-identidad que se encuentran alineados en el colapso. En la posmodernidad, la imagen-acción e inclusive la imagenmovimiento tienden a sumarse en beneficio de las situaciones bolañianas. La narrativa es una totalidad óptica, sonora e insoportable de las imágenes cuando se han vuelto demasiado fuertes. 


\section{Bibliografía}

Augé, Marc. Los no lugares. Espacios de anonimato. Una antropología de la sobremodernidad. Barcelona: Gedisa, 1992.

Allen, Graham. Intertextuality. London: Ed. Routledge, 2000.

Barthes, Roland. Aproximación al estructuralismo. Buenos Aires: Galerna, 1970. . Análisis estructural del relato. Puebla: Premiá Editores, 1988.

Baudrillard, Jean. La transparencia del mal. Barcelona: Editorial Anagrama. 1991.

Bolaño, Roberto. Los detectives salvajes. Barcelona: Anagrama, 1998. . Putas asesinas. Barcelona: Anagrama, 2001. 2666. Barcelona: Anagrama, 2004.

Cáceres, Alexis Candia. “Todos los males el mal. La estética de la aniquilación en la narrativa de Roberto Bolaño" en Revista chilena de literatura núm.76, Santiago: Ed. Universidad Católica de Chile, 2010, pp. 43 - 70.

Calvino, Ítalo. Las ciudades invisibles. Madrid: Siruela. 1998.

Cirlot, Juan Eduardo. Diccionario de Símbolos (1958). Madrid: ediciones Siruela, 2006.

Durand, Gilbert. Las estructuras antropológicas del imaginario. México: Fondo de Cultura Económica. 2004.

Espinosa, Patricia. "Tres de Roberto Bolaño, el crac a la posmodernidad". En: Territorios en fuga, Santiago de Chile: Frasis Editores, 2003.

García Canclini, Néstor. La sociedad sin relato. Antropología y estética de la inminencia. Buenos Aires: Katz editores, 2010, p. 160.

Geertz, Clifford. La interpretación de las culturas. Barcelona: Gedisa, 2003.

Genette, Gérard. Figuras. Retórica y Estructuralismo. Córdoba: Nagelkop, 1970. . Palimpsestos. La literatura en segundo grado. Madrid: Taurus, 1989.

González, Daniuska. "Un asunto tenebroso. La construcción del sujeto literario en Roberto Bolaño". En Anales de la literatura chilena. Venezuela, 2008.

Gutiérrez Zermeño, Griselda. Violencia sexista: algunas claves para la comprensión del feminicidio en Ciudad Juárez. México, Universidad Nacional Autónoma de México: Programa Universitario de Estudios de Género, México, 2004.

Heidegger, Martin. Ser y tiempo. Santiago de Chile: Universitaria, 1927.

Kertész, Imre. Yo, otro. Crónica del cambio. Barcelona: Acantilado, 2002.

Lainck, Arndt. Las figuras del mal en 2666 de Roberto Bolaño, Umschlagbild:

Ed. Lit, 2014.

Lipovetsky, Gilles. La era del vacío. Ensayos sobre el individualismo contemporáneo. Barcelona: Anagrama, 1992.

Lotman, Yuri Mijáilovich. La estructura del texto artístico. Madrid: Istmo, 1988. Luche, Laura. "La imagen de las vanguardias en la literatura nazi en América de Roberto Bolaño”. En Boletín Mi llares Carlo, Sassari: Ed. Umschlagbild, 2014. 
Nava, Osvaldo (Coord.). Tierras de nadie, México: Fondo Editorial Tierra Adentro. 2012.

Ogien, Ruwen. Pensar la pornografía. Barcelona: Paidós, 2003.

Pimentel, Luz Aurora. El espacio en la ficción/ficciones espaciales: la representación del espacio en los textos narrativos. México: Siglo XXI / UNAM, 2001.

Poblete Alday, Patricia. "El balido de la oveja negra la obra de Roberto Bolaño en el marco de la Nueva Narrativa Chilena". Madrid: Ed. Universidad Complutense de Madrid, 2006.

Solano, Francisco de. "Las voces de la Ciudad de México. Aproximación a la historiografía de la Ciudad de México", en VV.AA., La ciudad. Concepto y obra. México: UNAM, 1987.

Sinno, Neige. Lectores entre Líneas. Roberto Bolaño, Ricardo Piglia y Sergio Pitol. México: Editorial Aldus, 2001. 